\title{
CONSIDERING PLANNING APPROACHES IN THE GLOBAL SOUTH AND LEARNING FROM CO-PRODUCTION IN SOUTH AFRICA'S INFORMAL BACKYARD RENTAL SECTOR
}

\author{
LOUIS G. LATEGAN \& ELIZELLE J. CILLIERS \\ Unit for Environmental Sciences and Management, Urban and Regional Planning, \\ North-West University, South Africa
}

\begin{abstract}
The global South has traditionally been regarded as oppressed and subjugated, grappling to reach western ideals on the appropriate, desirable and modern. However, framing the developing world as such, fails to recognise that western norms may be neither feasible nor appropriate in these regions and discounts the value of alternative, mostly informal, approaches to provide outcomes more suited to the global South status quo. This paper aims to showcase how western standards and development mechanisms are still propagated in the developing world and how local populations adapt to the outcomes of such approaches to suit their needs and circumstances, in the process challenging western norms and shaping the city from below. The paper employs a qualitative research methodology based on a literature review of core concepts, including: the right to the city, spatial justice, co-production, modernism and neoliberalism; before turning to a case study of South Africa and its informal backyard rental sector to explore research objectives. The subsequent discussion frames the informal backyard rental sector as an example of the interface between the formal and informal; the state and civil society; and the global North and global South. Accordingly, presenting informal backyard rentals as a manifestation of co-production that provides fertile ground to rethink western ideals and reframe urban planning theory, policy-making and practice towards a more inclusive understanding based on lived experience. The paper concludes that such reconsidered approaches may hold potential for more sustainable and just settlements in South Africa and rest of the global South, but also for the cities of the global North, where issues like informality are increasingly imbedded in the urban landscape.

Keywords: global South, co-production, formal-informal dichotomy, informal backyard rentals, South Africa.
\end{abstract}

\section{INTRODUCTION}

Urban planning is unavoidably context defined. As a consequence, planning ideas cannot be imported and applied from one context to another under the pretext of universally held truths or based on general applicability. Varied socio-spatial, economic and environmental constructs demand equally varied planning theories and practical applications [1]-[3]. The western world, or global North, has historically played host to the development of the majority of the planning theories and urban models that continue to dominate the field of planning globally [4], [5]. However, it has become increasingly apparent that generalised planning theories and models from the North are often of limited relevance in the contexts of the global South [3], in Latin America, Asia and Africa. The global South often presents dramatic contrasts to the conditions that guide urban planning and development in the global North [5], personified by ethnically divided societies, poor infrastructure, poverty, political instability, weak public institutions, vast informal sectors and juxtapositions between the starkly modern and defiantly traditional. Such contrasting challenges have increasingly drawn the attention of the international planning community [4], [6] and form part of the rationale behind this paper. The paper is further motivated by the fact that $95 \%$ of urban expansion will concentrate in the developing world in the future [7] and the realisation that 
planning will never succeed in its normative purpose to establish a 'better' future [2], [8], [9], if planners fail to register a sensitivity towards Southern contexts and act accordingly. In pursuing a 'better' future the paper also draws on established concepts and theories, such as spatial justice, the right to the city and co-production before confronting forces such as modernism and neoliberalism as part of the literature review.

\section{LITERATURE REVIEW}

\subsection{The just city, spatial justice and the right to the city}

The just city promotes equal rights rooted in a moral obligation based on the ideas of equity, diversity and democracy [10]. According to Rawls [11] the allocation of goods in society should follow the 'difference principle' through which the already privileged should only benefit when 'doing so is to the advantage of those less fortunate'. Accordingly, advancing societal egalitarianism with the needs of the poor and marginalised equally articulated and met. Egalitarianism is also a cornerstone in French philosopher Henri Lefebvre's work. Lefebvre's 'right to the city' slogan has gained broad academic recognition [12]. Today the idea of spatial justice and the 'spatialisation' of issues on democracy and human rights revive Lefebvre's right to the city [13] as he defined space according to it social relations, as an alternative to the physical, demographic and territorial parameters traditionally used to define it [14], [15]. As such, space becomes a principal of production and reproduction, understood as contributing to inequality and injustice [16]. Spatial injustice can manifest in various ways, through locational discrimination and enduring spatial structures that empower privilege and oppression, often in pursuit of progressive and modern development aspirations.

\subsection{Modernism}

Urban planning in many parts of the world is still closely linked to Modernism and its ideals on a superlative end state that would deliver the 'good city'. The modernist city is largely based on harmony, formality and symmetry, the functional specialisation of areas and movement, the free flow of traffic, connectivity, vertical building, open space development and slum removal [17]. The last is especially significant in terms of this paper, with the will to order and formalise cited as part of 'high modernist ideology' intended to arrive at 'the rational design of social order commensurate with the scientific understanding of natural laws' [18]. Modernism is touted as a western concept [19], imagined by masters like Le Corbusier who conjured visions of modern skyscrapers and European promenades and boulevards [17]. Modernism entered the global South on the heels of colonialism and later globalisation, augmented in a stubborn confidence that progress towards the modern is desirable and possible [20].

Whilst the fall of colonialism and the rise of independence across the global South ushered in new liberties and freedoms to do away with unsuited western prescripts and development trajectories, most post-colonial governments were inclined to maintain and entrench colonial era spatial plans and land management tools, sometimes in more rigorous terms than under colonial occupation [21]. Through such trajectories the modernist vision was kept alive, fuelled by the ambition to 'catch up' and 'match' the global North economically and culturally with cities administrated by resilient and stable municipalities, populated by formally employed households who own cars and are moderately well-off [17]. Today, the new master plans for some of Africa's largest cities continue on the course and seem to depart even more radically from Africa's urban realities than before. These master 
plans propose urban utopias that rely on the continent's imminent 'rise', reflecting references to India and China. Accordingly, African master plans now conjure visions of Shanghai, Singapore or Dubai [22]. However, conceptualising Africa as a place of struggle and failure, trailing behind the rest of world in desperation to reach western ideals is ignorant and patronising, reflecting outdated outlooks on the recognition of the Southern world in grand human history only if these regions convert to Northern modernity [19]. The persistent obsession to force Africa and the rest of the global South into the 'modern age' has not served it well, with the neoliberal development philosophies that have accompanied such attempts having been absolutely destructive [23].

\subsection{Neoliberalism}

Neoliberalism is a theory of political economic practice that purports the liberation of 'individual entrepreneurial freedoms and skills within an institutional framework characterised by strong private property rights, free markets, and free trade' [24], with a benign yet frequently directive state needed to incite competitive, entrepreneurial, acquisitive and commercial behaviour [25]. For the neoliberalists privatisation becomes central [26] with the emphasis placed on profit and serving the greater good efficiently and effectively on the basis of cost-benefit analyses [16]. As an acute example of the outcomes of neoliberal approaches, certain residents may be displaced if the result benefits the majority even marginally, regardless of the impacts levied on those who are displaced who may already come from disadvantaged groups. In certain cases, such outcomes may benefit the already advantaged elite and further disadvantage those truly in need of aid [16], [26], with ramifications for spatial justice and their right to the city.

\subsection{The formal-informal dichotomy}

Modernist ideals in chase of the 'good city', often pursued through failed colonialist and postcolonial efforts to reach western development standards through neoliberal mechanisms have often clashed with a reality that is not as easily ordered or coerced. The modern is expressed in the formal, whilst the 'anomalies' that oppose it is framed as the informal [27]. It is important to note that the binary is defined according to what the west describes as 'normal' [17]. Within the dualistic classification the formal is implicitly cast as positive, whilst the informal is expelled as a problematic symptom relegated to the developing world [28]. In expression of the distinction, the informal is often described in terms of 'slums', suggesting the illegal, irrational, disordered and unwanted, an irritation or urban pathology to be cured [29]. Accentuating only the negative consolidates the notion of opposition between the formal and informal, and of the latter as an entity found far removed from the formal, planned and modern. In reality, the informal finds itself both within and outside the system [30]. Formal planning elicits the informal by distinguishing between activities as formal or informal, or indeed as more or less legal, by authorising or denouncing activities from one sector to the other [31]. Classifying activities as either formal or informal can also be used as a mechanism of control to contain the 'ungovernable' and condemn entire communities to the urban fringe, veiled behind the pretence of a civil and democratic urban governance system [17]. In such cases placing informality 'central to the urban planning regime' [32]. Furthermore, informality may be used deliberately as political leverage when support is exchanged on the promise of service delivery [30] or protection from eviction and eradication. In such cases informality is actively employed for political control or economic 
gain to the benefit of select interests [17], in what is known as the 'dark side of planning' [33].

Dark planning motives take advantage of vulnerabilities that are often created by the formal system itself, as informality is commonly accessed as a deliberate choice or last resort in the absence of alternative formal shelter or commercial options or because formal provisions are too costly or rigid [34]. Consequently, the informal primarily meets basic human needs [27] or secondarily responds to the restrictions imposed under formalised systems, often in reaction to or in conjunction with state-driven practices [30]. The latter may be termed co-production.

\subsection{Co-production}

Co-production is traditionally defined as: 'a process through which inputs from individuals who are not 'in' the same organisation are transformed into goods and services' [35]. In the context of this paper, co-production signifies the joint production of land and services by the state and citizens, with elements of the process shared amongst both. As such, both actors fulfil a role in situations where the state does not have the capacity to deliver or regulate independently, and low-income citizens cannot depend on their own systems or resources either, thus necessitating hybrid forms of production [6], [36], [37]. Co-production is often an organic manifestation in such circumstances, expressed clearly through unplanned and unsanctioned practice in the informal sector. It is important to recognise the role of hybridised forms of service delivery for the poor and disenfranchised who may use services delivered by the state to survive, even when these services are not directly intended for them. In such examples the formal, as the state and its services, and the informal, as those disadvantaged groups that utilise those services without permission, meet one another and often intersect. In these grey areas spaces and actors are established that blur the line between the formal and informal, being neither completely integrated nor eradicated [38]. Through such coproductive practices citizens may exercise an appropriated right to an often-unjust city. Whilst informal practices may be somewhat tolerated in such circumstances, informality is rarely officially sanctioned, as official recognition or endorsement would oppose the ideals of progressive modern development (see section 2.2).

The following segment introduces the paper's empirical research section, opening with a brief positioning of Africa in the global South, laying the foundation for the case study of South Africa's informal backyard rental sector and the discussion of the sector as an example of co-production that follows.

\section{EMPIRICAL STUDY}

\subsection{Methodology}

This study makes use of a qualitative approach, drawing on a desktop analysis and theory based sampling, incorporating key elements discussed in the literature review to link a case study of South Africa's informal backyard rental sector to co-production and highlight the significance for future planning endeavours for the global South. As in the literature review above, the case study and subsequent discussion rely on a variety of sources identified using electronic databases and academic search engines, with search queries related, inter alia, to the global South, planning theory, informality, informal backyard rentals, co-production and transferability. 


\subsection{A perspective on Africa and South Africa}

Africa has been singled out in debates on the global South, as the continent especially faces acute challenges [34]. Africa displays vastly uneven patterns of urban and economic development across its immense landscape [39]. Accordingly, generalisations on Africa will likely be confronted with contradictions from specific non-conforming instances from one African case to another [1]. Yet, it would also be negligent to assume that different African countries, and countries throughout the global South, do not share certain characteristics given the histories and contemporary challenges they may have in common. The danger of irresponsible generalisation is ever present, but is partially surmounted by a communal history of colonialism that continues to unite much of the African continent and developing world. It is also within this shared history that scholars may confront and overcome the notion of South African exceptionalism, with the country often referenced as a marginal member of the western world [40], and may include South Africa in African and global South scholarship [23]. It is from this understanding that this paper focuses on South Africa as case study.

Though an extensive period of colonial rule features in South African history, the policy of apartheid is most synonymous with western domination in the country today. The apartheid city model entrenched colonial values on the control of native populations according to modernist principles for urban design and housing [41]. As a system of race based planning and development, apartheid left a heritage of significant housing shortages for the Black population in its wake in the early to mid-nineties. The post-apartheid government responded with a constitutionally mandated commitment to housing, resulting in housing delivery at an unprecedented scale and pace in pursuit of restorative justice. Despite valiant efforts, the housing backlog has continued to expand as approaches have resulted in large, but dwindling numbers of uniform units that disregard beneficiary needs [42], [43] within a neoliberal policy framework aimed at developing internationally competitive cities [1], [12]. Despite a fixation on eliminating informality through extensive slum eradication programmes in accordance with international norms, informal development practices have intensified [44], [45], signifying a renewed struggle for Lefebvre's the right to the city [12]. Informality has strengthened its presence in the South African shantytown and increasingly in low-income suburbs and the state's subsidised housing projects, evidenced by an overwhelming number of illegal electricity and water connections, informal businesses and informal backyard (rental) structures [46].

\subsection{South Africa's informal backyard rental sector}

An informal backyard rental structure is defined as: 'An informal structure erected by a recognised property owner or tenant within the boundaries of a formally registered property that contains at least one formal dwelling unit. The materials and construction practices used do not comply with National Norms and Standards with the structure constructed attached or adjacent to an existing formal dwelling. An oral or written agreement or 'understanding' may be negotiated that provides permission for settlement and may include terms of rental remuneration, conditions of service access, eviction procedures and other landlord and tenant rights' [47]. The number of informal backyard rental structures in South Africa was estimated at a conservative and questionable 756,000 households in 2014 [47]. These structures address the need for affordable rental housing neglected by official policies, accommodating those who would otherwise settle in shantytowns, often in convenient locations, densifying suburbs, capitalising on existing infrastructure and housing investments, providing landlords 
and tenants with financial benefits and building social capital. Conversely, informal backyard rentals also pose several health and safety risks, may introduce overcrowding, overburden infrastructure networks and degrade the environment (For detailed discussions, see [47]). Despite the informal backyard rental sector's ubiquity, potentials and challenges, the segment is not yet addressed by any national policy [48]. The neglect of the informal backyard rental sector symbolises a system unable to respond to the context-specific challenges it faces, preoccupied with reaching a western development ideal and disregarding reality. Through the exclusion of the informal backyard rental sector [49] and blunt housing policy unable to respond to housing needs either sustainably or at scale [50], South African planning continues to fail in its normative purpose.

Although conflict and the threat of eradication remain (see Section 3.2), backyarders have carved out their own niche in the South African housing market through persistence and constant defiance of building regulations, zoning requirements and density guidelines based on conventions more appropriate to western contexts. As such, backyarders force the state to accept their presence and gradually adapt the official response from one of total indifference focused on eradication to increased recognition, legitimisation and future support. The gradual shift is demonstrated in the South African state's commitments to produce national policies on back yarding in the future [51], not intent on eradicating the sector, but on agonistically supporting and encouraging the informal rental market as an autonomous people-led response to the housing backlog based on co-productive relationships.

\section{DISCUSSION}

\subsection{The informal backyard rental sector, co-production and related significance}

It is in providing a real-world example of co-production that South Africa's informal backyard rental sector is especially significant. Informal backyard rentals are not the result of deliberate state-led attempts to encourage self-help housing or hybridisation in acknowledgement of its own shortcomings. Instead, the sector originates at grassroots level within a culture of informal development established during the later years of apartheid [52], and maintained as an unintended by-product of formal housing delivery outcomes [53], in the democratic era [50]. Informal backyard rentals are produced as the current government remains unable to meet the extreme housing backlog [54] and the poor are incapable of accessing housing without drawing on some form of support. Within this context, informal backyard rentals bridge shortfalls for both the state and destitute, accordingly meeting the definition on co-production provided earlier [55]. This paper further posits that the informal backyard rental sector provides an example of co-production in service delivery, but also within the North-South debate. It is within these often-hidden backyard spaces that western inspired modernist aspirations of control embodied by housing development schemes, meet an opposing South African reality. In these spaces attempts to order and rationalise according to western conventions are confronted by and amalgamate with an indigenous system based on survival. It follows that the informal backyard rental sector establishes an intriguing interface between the formal and informal and the global North and global South. The interface presents a struggle in which unpredictable and diverse forms of engagement are established, with both positive and more negative results [17]. As such, it is important to note that co-production may not be exclusively positive, but as with the informal backyard rental sector, may exhibit 'mutually enhancing and mutually corrupting' properties [37]. Yet, it is within these conflicted spaces that the most thought-provoking opportunities for learning and understanding are presented to produce effective new planning ideas [3], [17], that recognise 
the indifference and limits of official approaches and the ingenuity found in ground level responses. In the case of the informal backyard rental sector's co-productive continuation, these deficiencies and responses are evidenced physically in great numbers and provide ample opportunities for future planning strategies to capitalise on existing potentials and mitigate risks and challenges towards improved quality of life. Recommendations in this regard are captured in the Conclusions section below.

Examining varied cases of co-production from the global South may furthermore advance the internationalisation of planning by recognising forms of alternative development and planning engagement already established across varying global contexts [6]. In working transnationally, global influences and experiences may constantly inform and challenge perceptions on how the world works and develops [2]. This is important in challenging dominant perceptions about the struggles and opportunities presented outside the global North and in accepting that experience from Euro-America may not apply universally and may more likely be exceptional in the international context [56]. As such, opposing the idea of informality as the exception and not the norm [37] and as problematic entity found outside and far removed from the formal is especially significant. In advocating a shift from Northern dominance, theorists have called for a departure from the frequently uncontested image of the African, or any other Southern city as a place of failure, perpetually in need of intervention from the North [3]. In heeding, this call the planning community at large might start to view these places not as instances of deteriorated modernity, but as examples both part of and separate from conventional interpretations of the modern established through the resourceful responses of citizens to their own vulnerabilities. In this regard, accepting and exploring a new kind of Afro-modernity [19]. Such interpretations may allow for more positive conceptualisations that acknowledge successes or potentials despite structural constraints [4]. Delivering this message and garnering support for the cause will require a shift towards an appreciation of a real-world perspective based on empiricism, everyday experience and indigenous knowledge (see [3], [34]). A legitimised focus on the everyday may confer a level of respectability to modes of local knowledge and practice dismissed as irrationalities or irrelevancies in the past [4]. These sentiments are supported by Watson [57], for whom the local empirical holds substantial value. She calls on planning research to re-establish its foundation in the empirical, not as a return to the critiqued empiricism of the past, but in order to relate theory to practically viable applications. Through such a reconsidered emphasis, contemporary research focused on the global South may elaborate on how regionally bound local experiences can contribute to planning thought at a broader global scale [58], placing a responsibility on the shoulders of those planners who find themselves in western contexts to learn from experiences in the global South [2], [4]. Accordingly, ways of thinking and theorising in Africa, based on phenomena such as coproduction, may show the way to the North [59], where issues such as informality are increasingly becoming part of the daily urban experience [30], [60] strengthening arguments that the North and South and all peripheries in-between might exist within each other [30]. Comaroff and Comaroff [19] summarise the sentiment aptly by stating: 'In short, there is much South in the North, much North in the South, and more of both to come in the future'.

Yet, such realisations should not convince planners that inter-contextual, transregional work will come without limitations, or that academics should promote simplistic 'best practice' ideals from one region to the other [17]. In the endeavour to generate Southern-based approaches, planners should be cautious of establishing artificial binaries between the global North and global South, and even from in-between Southern contexts. Whenever ideas are transferred it is vital that a contextual common ground be established that underpin the concept and may hold elsewhere [17]. This paper affirms the responsibility 
of planners to recognise and address potential distortions that may develop as ideas travel over time and become institutionalised or part of politicised attempts to dominate [2]. As such, Healey [2] emphasises the value of an 'origin narrative' that identifies the situation in which a concept was developed, describes its specific history and examines how it travelled from its site of origin to assist in identifying what can be learned from it of bearing to other contexts. An origin narrative may be useful in establishing a body of international research that circumvents the propensity to generalise based on 'best practice' and pursue decontextualized models that ignore the significance of place in shaping planning thought and practice [6]. In the same vein, planners should be wary of labelling all Northern-based concepts as irrelevant or unsuitable for the South [61]. As examples of promise, paradigms focussed on developing new urban forms such as compact city concepts with infrastructureled spatial plans and new urbanism provide important spatial principles that present alternatives to the spatial and urban forms propagated under urban modernism in much of the global South [17].

\section{CONCLUSION}

This paper strengthens the argument to abandon the notion of universal field theories and urban models that ignore contextual variances and are applied unilaterally across the globe, especially from North to South. The paper reinstitutes the need to acknowledge multiple rationalities and concede to alternative forms of modernism that may promote justice outside western prescripts on orderly and progressive development. The dominance of Northern influences, including colonialism, modernism and neoliberalism and examples such as South African apartheid, have stood in the way of planning to truly serve as a vehicle of justice towards a 'better future' in the global South. There is a need to establish a cadre of planners that can recognise misconceptions and prejudices, willing to learn from real-world experiences outside the confines of the global North. Overcoming the idea of Southern ineptitude will require a planning community situated both within and outside the global South that values grassroots experience and prioritises the normative purpose to 'better' the future, regardless of the ways in which such endeavours may correspond or clash with western conventions. In South Africa, planners need only notice what is happening in their own backyards, recognise local responses and respect the rights of insurgents who oppose plans to sweep them away and deny their right to the city. This will require out-of-the box thinking in two respects. Firstly, by confronting the relevance and sovereignty of the standard subsidised housing product provided under national housing programmes, as a physical box intended to enforce a very westernised way of modern living. Secondarily, by planners becoming advocates for the marginalised, encouraging grassroots participation and taking outcomes on board in future policies and planning decisions. As such, planners and policymakers may acknowledge the benefits and challenges encapsulated in the informal backyard rental sector by recognising the sector officially and facilitating informal backyard renting in partnership with landlords and tenants. Accordingly, policies may shift away from eradication objectives, introduce larger stand sizes to accommodate informal backyard rentals, consider informal rental subsidies, support programmes, targeted stakeholder engagement platforms, conflict mediation services, building training programmes, fire and health checks, revised zoning and building restrictions, all mandated at local level and based on local needs. It is within such a framework that planners can show support for Southern potential and the kind of Afro-modernity established through co-production exemplified by the informal backyard rental sector. Through such shifts and based on the argument for responsible transnational and interregional theorising and practice a planning community may be established in which the world is equally represented, localised work is appreciated 
and contextual relevance guides how planning ideas are generated, imported, exported, accepted and institutionalised towards more sustainable and 'better' futures in both the global North and global South.

\section{ACKNOWLEDGEMENTS}

The financial assistance of the National Research Foundation (NRF) towards this research is hereby acknowledged. Opinions expressed and conclusions arrived at, are those of the authors and are not necessarily to be attributed to the NRF. The financial assistance of the North-West University's Unit for Environmental Sciences and Management is also acknowledged. This paper is inspired by a $\mathrm{PhD}$ thesis, entitled 'Informality and sustainability: Reflecting on South Africa's informal backyard rental sector from a planning perspective' completed at the North-West University, penned by the paper's main author.

\section{REFERENCES}

[1] Friedmann, J., Review: Globalization and the emerging culture of planning. Progress in Planning, 64, pp. 183-234, 2005.

[2] Healey, P., The universal and the contingent: Some reflections on the transnational flow of planning ideas and practices. Planning Theory, 11(2), pp. 188-207, 2012.

[3] Ernstson, H., Lawhon, M. \& Duminy, J., Conceptual Vectors of African Urbanism: 'Engaged Theory-Making' and 'Platforms of Engagement'. Regional Studies, 48(9), pp. 1563-1577, 2014.

[4] Harrison, P., On the edge of reason: Planning and urban futures in Africa. Urban Studies [Routledge]. 43(2), pp. 319-335, 2006.

[5] Watson, V., Engaging with citizenship and arban struggle Through an informality lens. Planning Theory and Practice, 12(1), pp. 150-153, 2011.

[6] Watson, V., Co-production and collaboration in planning - The difference. Planning Theory \& Practice, 15(1), pp. 62-76, 2014.

[7] United Nations. Sustainable Development Goals: 17 Goals to Transform Our World; Facts and Figures 2015 (15 October 2015). Online. http://www.un.org/ sustainabledevelopment/cities/\#f3c52f92070201572. Accessed on: 12 May 2017.

[8] Bond, S., Negotiating a 'democratic ethos': Moving beyond the agonistic communicative divide. Planning Theory, 10(2), pp. 161-186, 2011.

[9] Campbell, H., Tait, M. \& Watkins, C., Is There Space for Better Planning in a Neoliberal World? Implications for Planning Practice and Theory. Journal of Planning Education and Research, 34 (1), pp. 45-59, 2014.

[10] Uitermark, J.S., Fainstein: The just city. Journal of Housing \& the Built Environment, 27(1), pp.107-109, 2012.

[11] Rawls, J., A theory of justice: Cambridge, Mass. : Belknap Press, 2005. c1971. Original ed. 2005.

[12] Huchzermeyer, M. Invoking Lefebvre's 'right to the city' in South Africa today: A response to Walsh. City, 18(1), pp. 41-49, 2014.

[13] Soja, E.W., The city and spatial justice. La ville et la justice spatiale; March 12-14, 2008; Nanterre, Paris, 2009.

[14] Lefebvre, H., La droit à la ville. Paris: Éditions Anthropos, 1968.

[15] Lefebvre, H., La révolution urbaine. Paris: Gallimard, 1970.

[16] Fainstein, S.S., The just city. International Journal of Urban Sciences, 18(1), pp. 118, 2014.

[17] Watson, V., "The planned city sweeps the poor away...": Urban planning and 21 st century urbanisation. Progress in Planning, 72, pp. 151-193, 2009. 
[18] Scott, J., Seeing Like a State New Haven and London: Yale University Press, 1998.

[19] Comaroff, J. \& Comaroff, J.L., Theory from the South: Or, how Euro-America is Evolving Toward Africa. Anthropological Forum, 22(2), pp. 113-131, 2012.

[20] Schrijver, L., Utopia and/or Spectacle? Rethinking Urban Interventions Through the Legacy of Modernism and the Situationist City. Architectural Theory Review, 16(3) pp. 245-258, 2011.

[21] Njoh, A., Planning in contemporary Africa: The state town planning and society in Cameroon. Aldershot, UK: Ashgate; 2003.

[22] Watson, V., African urban fantasies: Dreams or nightmares? Environment and Urbanization, 26(1), pp. 215-231, 2014.

[23] Watson, V., The usefulness of normative planning theories in the context of SubSaharan africa. Planning Theory, 1(1), pp. 27-52, 2002.

[24] Harvey, D., A brief history of neoliberalism: Oxford, Oxford University Press, 2005.

[25] Gilbert, J., What kind of thing is 'Neoliberalism'? pp. 7-22, 2013.

[26] Aalbers, M.B., Neoliberalism is Dead ... Long Live Neoliberalism! : Wiley-Blackwell, pp. 1083-1090, 2013.

[27] Kamete, A.Y., On Handling Urban Informality in South Africa. Geografiska Annaler: Series B, Human Geography, 95(1), pp. 17-31, 2013.

[28] Lombard, M. \& Huxley, M. Self-Made Cities: Ordinary Informality? Planning Theory \& Practice, 12(1), pp. 120-125, 2011.

[29] Revell, K., Working with informality: increasing resilience in cities of the Global South. 46th ISOCARP Congress 2010; Nairobi, Kenya, pp. 1-13, 2010.

[30] Miraftab, F., Insurgent planning: Situating radical planning in the global south. Planning Theory, 8(1), pp. 32-50, 2009.

[31] Roy, A., Strangely familiar: planning and the worlds of insurgence and informality. Planning Theory, 8(1), pp. 7-11, 2009.

[32] McFarlane, C., Rethinking Informality: Politics, Crisis, and the City. Planning Theory \& Practice, 13(1), pp. 89-108, 2012.

[33] Yiftachel, O., Planning and social control: Exploring the dark side. Journal of Planning Literature, 12(4), p. 395, 1998.

[34] Blanco, H., Alberti, M., Olshansky, R., Chang, S., Wheeler, S.M., Randolph, J. et al., Shaken, shrinking, hot, impoverished and informal: Emerging research agendas in planning. Progress in Planning, 72, pp. 195-250, 2009.

[35] Ostrom, E., Crossing the great divide: Coproduction, synergy, and development. World Development, 24, pp. 1073-1087, 1996.

[36] Mitlin, D., With and beyond the state - Co-production as a route to political influence, power and transformation for grassroots organizations. Environment and Urbanization, 20(2), pp. 339-360, 2008.

[37] McFarlane, C. \& Waibel, M., Introduction: The Informal-formal Divide in Context. Urban Informalities. Surrey, England: Ashgate Publishing Limited, pp. 1-12, 2012.

[38] Yiftachel, O., Theoretical notes on gray cities: The coming of urban apartheid? Planning Theory, 8(1), pp. 88-100, 2009.

[39] Odendaal, N., Reality check: Planning education in the African urban century. Cities, 29, pp. 174-182, 2012.

[40] Dewar, D., Can South Africa survive?: five minutes to midnight. In: Brewer, J.D., ed. Macmillan; Southern Book Publishers, 1989.

[41] Haarhoff, E.J., Appropriating modernism: Apartheid and the South African Township. A/Z ITU Journal of the Faculty of Architecture, 8(1), pp. 184-195, 2011. 
[42] Lizarralde, G., Stakeholder participation and incremental housing in subsidized housing projects in Colombia and South Africa. Habitat International, 35, pp. 175$187,2011$.

[43] Lorraine, M.M. \& Molapo, R.R., South Africa's challenges of realising her socioeconomic rights. Mediterranean Journal of Social Sciences, 5(27), pp. 900-907, 2014.

[44] Turok, I. \& Borel-Saladin, J., Is urbanisation in South Africa on a sustainable trajectory? Development Southern Africa, 31(5), pp. 675-691, 2014.

[45] Tomlinson, M.R., South Africa's Housing Conundrum. In: Cronje F., Jeffery A., Moloi L., Dimant, T.C., eds. @ Liberty: The policy bulletin of the IRR. 4: South African Institute of Race Relations, pp. 1-7, 11-14, 2015.

[46] Massey, R.T., Exploring counter-conduct in upgraded informal settlements: The case of women residents in Makhaza and New Rest [Cape Town], South Africa. Habitat International, 44, pp. 90-96, 2014.

[47] Lategan, L.G., Informality and Sustainability: Reflecting on South Africa's informal backyard rental sector from a planning perspective. $\mathrm{PhD}$ thesis. North-West University, South Africa, pp. 1-529, 2016.

[48] Zwaig, P.J., Everyday hazards and vulnerabilities amongst backyard dwellers: A case study of Vredendal North, Matzikama Municipality, South Africa. Jàmbá: Journal of Disaster Risk Studies, 7(1), pp. 1-8, 2015.

[49] Rubin, M. \& Gardner, D., Developing a Response to Backyarding for SALGA. pp. 1-93, 2013.

[50] Wertman, C.A., There's no place like home: Access to housing for all South Africans. Brooklyn Journal of International Law, 40(2), pp. 719-747, 2015.

[51] RSA., Department of Human Settlements: Medium term strategic framework for 2014-2019 (MTSF). 2014.

[52] Shapurjee, Y., Le Roux, A. \& Coetzee, M., Backyard housing in Gauteng : an analysis of spatial dynamics. Stads- en Streeksbeplanning/Town and Regional Planning, 64, pp. 19-30, 2014.

[53] Lemanski, C., Augmented informality: South Africa's backyard dwellings as a byproduct of formal housing policies. Habitat International, 33, pp. 472-484, 2009.

[54] Turok, I., South Africa's new urban agenda: Transformation or compensation? Local Economy, 31(1),(2), pp. 9-27, 2016.

[55] Shapurjee, Y. \& Charlton, S., Transforming South Africa's low-income housing projects through backyard dwellings: Intersections with households and the state in Alexandra, Johannesburg. Journal of Housing and the Built Environment, 28(4), pp. 653-666, 2013.

[56] Seekings, J. \& Keil, R., The International Journal of Urban and Regional Research: An Editorial Statement. International Journal of Urban and Regional Research, 33(2), pp. 1-10, 2009.

[57] Watson, V., Conflicting rationalities: Implications for planning theory and ethics. Planning Theory and Practice, 4(4), pp. 395-407, 2003.

[58] Visser, G., Looking beyond the urban poor in South Africa: the new terra incognita for urban geography. Canadian Journal of African Studies, 47(1), pp. 75-93, 2013.

[59] Connell, R., Using southern theory: Decolonizing social thought in theory, research and application. Planning Theory, 13(2), pp. 210-223, 2014.

[60] Porter, L., Lombard, M., Huxley, M., Ingin, A.K, Islam, T., Briggs, J. et al., Informality, the Commons and the Paradoxes for Planning: Concepts and Debates for Informality and Planning Self-Made Cities: Ordinary Informality? The Reordering of 
a Romany Neighbourhood The Land Formalisation Process and the Peri-Urban Zone of Dar es Salaam, Tanzania Street Vendors and Planning in Indonesian Cities Informal Urbanism in the USA: New Challenges for Theory and Practice Engaging with Citizenship and Urban Struggle Through an Informality Lens. Planning Theory \& Practice, 12(1), pp. 115-153, 2011.

[61] Parnell, S. \& Robinson, J., (Re)theorizing cities from the global south: Looking beyond neoliberalism. Urban Geography, 33(4), pp. 593-617, 2012. 